\title{
TRADYCJE APOKRYFICZNE W POEZJACH BOŻONARODZENIOWYCH KASPRA MIASKOWSKIEGO
}

Choć uchwały Soboru Trydenckiego i postanowienia obradującego w Gnieźnie synodu prowincjonalnego (1589) nie pozostawiały wątpliwości co do pejoratywnej oceny pozakanonicznego piśmiennictwa, komponenty apokryficzne były w siedemnastowiecznej katolickiej literaturze religijnej, zwłaszcza tej o tematyce bożonarodzeniowej, żywotne i trwałe ${ }^{1}$. Elementy apokryficzne pojawiają się w: Wirydarzu Stanisława Grochowskiego, Kolebce Jezusowej Kaspra Twardowskiego, Symfonijach anielskich Jana Żabczyca i innych kolędowych tekstach będących w XVII wieku w obiegu czytelniczym w Polsce. Sam Piotr Skarga, który w Żywocie św. Anny wyrzeka na „bluźnierczą” i „szaleńczą" legendę o trzech małżeństwach świętej ${ }^{2}$ w kazaniu

${ }^{1}$ O negatywnej ocenie pozakanonicznego piśmiennictwa pisała m.in. Maria Adamczyk, Biblijno-apokryficzne narracje w literaturze staropolskiej do końca XVI wieku, Poznań 1980, s. 11-12. Autorka podejmuje tę kwestię również we wstępie do antologii staropolskich tekstów apokryficznych (Maria Adamczyk, Wstęp, w: Cały świat nie pomieścitby ksiąg. Staropolskie opowieści i przekazy apokryficzne, oprac. Wojciech Rzepka, Wiesław Wydra, Warszawa-Poznań 1996, s. 45-46).

2 Piotr Skarga, Żywot Ś. Anny Matki Bogarodzice z Doktorów kościelnych, z Epifaniusza i z Grzegorza Nyseńskiego i Hipolita męczennika i Damascena wybrany, w: tegoż, Żywoty Świętych Starego i Nowego Zakonu na każdy dzień przez cały rok, Kraków 1603, druk. Andrzeja Piotrkowczyka, s. 661. Zob. Maria Adamczyk, Wstęp, w: Cały świat nie pomieściłby ksiag..., dz.cyt, s. 21. Przywołując pozakanoniczną postać św. Anny, Piotr Skarga powołuje się raczej na autorytet pisarzy wczesnochrześcijańskich niż na apokryficzne pisma. Por. Maria Adamczyk, Wstęp, w: Cały świat nie pomieściłby ksiąg.., dz.cyt., s. 20. 
Na dzień Trzech Króli lokuje pokłon Mędrców w „szopie zgniłej”, niewiele martwiąc się przy tym faktem, że Wulgata przecież sytuuje scenę w domu, domostwie (łac. domus, Mt 2,10 ). Pozakanoniczna jest nawet przywołana w kazaniu (a zarazem powszechna) nazwa przybyszów ze Wschodu - autor natchniony nie wspomina przecież ani słowem o królewskim pochodzeniu betlejemskich gości (Mt 2,1). U Skargi zwraca uwagę znacznie amplifikowany względem lakonicznej wzmianki autora natchnionego (Mt 2,11 - „[...] i upadłszy, pokłonili się Jemu”) opis adoracji Dzieciątka:

I [...] pokłonili się pierwej na kolana, potem padli na twarze swoje, jako Bogu swemu: i przystąpiwszy, nogi Dzieciąteczka całowali, i z taką się pokorą uniżyli, jako stworzeniu przeciw Stworzycielowi swemu przystojna jest ${ }^{5}$ [podkr. P.G.].

Soborowe uchwały i postanowienia polskich władz kościelnych nie wyrugowały zatem wszystkich apokryficznych motywów i fabuł, gdyż te okazywały się niezbędnym komponentem wyobraźni religijnej i tym samym ważnym tworzywem medytacji, rozważań czy po prostu pobożności popularnej, której w żadnym wypadku nie należało osłabiać w konfrontacji z wyznaniami reformowanymi. Przyczyn trwałości niektórych pozakanonicznych elementów należałoby też upatrywać w oficjalnym kalendarzu liturgicznym (przewidującym, przykładowo, uroczystość „Trzech Króli”, a nie - „Mędrców ze Wschodu"), a także w - liturgicznych (związanych z celebracją świąt)

${ }^{3}$ Piotr Skarga, Na dzień Trzech Królów kazanie krótkie, w: tegoż, Żywoty Świętych..., dz.cyt., s. 26.

4 Biblia sacra Veteris et Novi Testamenti. Secundum editionem vulgatam, t. 2, Basileae 1591, druk. Thomasa Guarina, s. 2. Pomyłka to chyba w czasach Miaskowskiego powszechna. O królach, którzy przyszli do „stajni”, pisze ks. Fabian Birkowski: „Rzeczesz: jedna tylo była gwiazda, ja dwie widzę, jedne na niebie, a drugą w stajni, przy żłobie, którą obaczyli Trzej Królowie, gdy weszli” (Fabian Birkowski, Kazanie na dzień Trzech Królów, w: tegoż, Kazania na święta doroczne, druk. Andrzeja Piotrkowczyka, Kraków 1620, s. 125).

${ }^{5}$ Piotr Skarga, Na dzień Trzech Królów kazanie krótkie, w: tegoż, dz.cyt., s. 27. 
i pozaliturgicznych - modlitwach Kościoła ${ }^{6}$. Takim locus uprzywilejowanym, w szczególny sposób aktywizującym tradycję apokryficzną była narratio Nativitatis - czy to w kazaniach, czy w upowszechnianych przez franciszkanów jasełkach ${ }^{7}$, czy wreszcie (a może przede wszystkim) w ikonografii ${ }^{8}$.

Poezja bożonarodzeniowa Kaspra Miaskowskiego jest dobitnym przykładem tego, jak wyobraźnię religijną potrydenckiego poety współtworzą motywy apokryficzne - nie dające się odeprzeć, wszechobecne i niemal niepostrzeżenie przenikające się z wątkami kanonicznymi, które w oficjalnym dyskursie pastoralnym rekomendowane są jako jedyne właściwe ${ }^{9}$. Poeta posługuje się tymi motywami ostrożnie i umiejętnie ${ }^{10}$. W przedstawieniu „możliwie pełnego obrazu wydarzeń" pomaga mu nie tylko kompilowanie kilku ewangelicznych relacji, lecz

6 Por. Andrzej Rutkowski, Objawienie Pańskie. Trzech Króli, w: Encyklopedia katolicka, t. 14, red. Edward Gigiliewicz, Lublin 2010, s. 181. Niektóre święta kościelne „wywodziły się wprost z apokryfów” (Marek Starowieyski, Wstęp, w: Apokryfy Nowego Testamentu. Ewangelie apokryficzne, t. 1, red. tenże, Kraków 2003, s. 52).

7 Por. Adam Karpiński, Objaśnienia, w: Jan Żabczyc, Symfonije anielskie, Warszawa 1998, s. 81. Koniec XVI i początek XVII wieku przyniósł gwałtowny wzrost franciszkańskich prowincji (250\%) i klasztorów (245\%) w Polsce. (Por. Zakony franciszkańskie $w$ Polsce, red. Jerzy Kłoczowski, t. 2: Franciszkanie w Polsce XVI-XVIII wieku, red. Henryk Gapski, Celestyn S. Napiórkowski, Niepokalanów 1998, s. 21-22).

${ }^{8}$ Por. Antoni Paciorek, Wstęp, w: Gdy Jezus narodził się w Beltejem... Ewangelia Dzieciństwa z komentarzem teologiczno-biblijnym i ikonograficznym, oprac. tenże, Urszula M. Mazurczak, Lublin 2005, s. 8-7.

9 Wpływ apokryfów na bożonarodzeniową twórczość poety nieczęsto bywał przedmiotem zainteresowania badaczy. Ważkie informacje na ten temat znajdują się przede wszystkim w dwóch, kluczowych dla badań nad poezją Kaspra Miaskowskiego, pracach: monografii Stefana Nieznanowskiego, O poezji Kaspra Miaskowskiego. Studium o kształtowaniu się baroku w poezji polskiej, Lublin 1965, i krytycznym wydaniu Zbioru rytmów w opracowaniu Aliny Nowickiej-Jeżowej (Kasper Miaskowski, Zbiór rytmów, oprac. Alina Nowicka-Jeżowa, Warszawa 1995). Cenne uwagi dotyczące tego problemu zawiera również rozprawa Mirosławy Hanusiewicz (Mirosława Hanusiewicz, Święte i zmysłowe w poezji religijnej polskiego baroku, Lublin 2001, s. 239-244).

10 Por. Alina Nowicka-Jeżowa, Wstęp, w: Kasper Miaskowski, Zbiór rytmów, dz.cyt., s. $5-6,8,9$. 
także łączenie różnych przekazów apokryficznych ${ }^{11}$. Występujące w bożonarodzeniowej poezji Miaskowskiego składniki, pochodzące ze źródeł pozakanonicznych, są najczęściej wobec siebie (i względem kanonicznych elementów) komplementarne, niekiedy jednak poeta zestawia je na zasadzie alternatywy, jak np. w Szopie zbawiennej:
Betle $<j>$ emskiej on grzbiet skały, jeszcze niżli mury wstały wykowany ręką prostą i pokrzywy po nim rostą, zgon bydlęcy, kiedy w znoju spieszy z pola w cień do zdroju abo cicha zimie szopa, gdzie wół z osłem czekał snopa.

(Szopa zbawienna, w. 1-8) $)^{12}$

Kasper Miaskowski przywołuje tu niemal wszystkie apokryficzne warianty miejsca narodzin Jezusa. Na początku utworu maluje grotę wykutą w skale przez prostych ludzi („ręką prostą”), później przechodzi do opisu miejsca przechodniego („zgon bydlęcy”), zajmowanego przez zwierzęta tymczasowo, by w finalnej części drugiej strofy przedstawić bardziej rodzimy obraz szopy osadzonej w zimowej scenerii. Dwa alternatywne obrazy ([... „gdzie dach odarty albo w ścienie skała") przedstawia też fragment Przemowy na rotuły (Rotuły, 2. Przemowa na rotuly, w. 140).

Kanoniczny przekaz (Łk 2,7) mówi o miejscu Narodzenia niewiele: po pierwsze, wydarzenia z pewnością nie rozgrywały się w gospodzie, po drugie, w środku znajdował się żłób, więc (pierwotnie lub aktualnie) wnętrze, w którym narodził się Jezus, było przestrzenią

\footnotetext{
11 O dążeniu do „pełnego obrazu wydarzeń” i kompilacji różnych przekazów ewangelicznych pisała Alina Nowicka-Jeżowa (Alina Nowicka-Jeżowa, Wstęp, w: Kasper Miaskowski, Zbiór rytmów, dz.cyt., s. 10).

12 Wszystkie cytaty utworów Miaskowskiego w niniejszym artykule pochodzą z krytycznej edycji Zbioru rytmów (Kasper Miaskowski, Zbiór rytmów, oprac. Alina Nowicka-Jeżowa, Warszawa 1995).
} 
zarezerwowaną dla zwierząt. Najstarsze teksty apokryficzne (lub lepiej - „apokryfy właściwe”"13) nie są już tak oględne i wyraźnie lokują narodziny Jezusa w „jaskini”"14 lub rzadziej - w "grocie”"15. Bywa, że dany apokryf podaje różne (a nawet sprzeczne) określenia, np. w Księdze o narodzeniu Zbawiciela, o Maryi i o położnej mowa zarazem o „jaskini”, jak i „stajni, stojącej na osobności”16. W polskim Rozmyślaniu przemyskim znajduje się wzmianka o niezajętym przez nikogo w owym czasie „domu pospólnym”" Najbliższy zaś Miaskowskiemu i - być może - dostępny poecie Żywot Pana Jezu Krysta Baltazara Opecia informuje, iż Maryja z Józefem weszli

${ }^{13}$ Nazwa zgodna z nomenklaturą stosowaną przez Marię Adamczyk (por. Maria Adamczyk, Wstęp, w: Cały świat nie pomieściłby ksiąg..., dz.cyt., s. 29.

14 Tak m.in.: Ewangelia Arabska Jana (Ewangelia Arabska Jana, w: Apokryfy Nowego Testamentu. Ewangelie apokryficzne, dz.cyt., s. 233), Protoewangelia Jakuba (Protoewangelia Jakuba, w: Apokryfy Nowego Testamentu. Ewangelie apokryficzne, dz.cyt., s. 282), Ewangelia Pseudo-Mateusza (Ewangelia Pseudo-Mateusza, w: Apokryfy Nowego Testamentu. Ewangelie apokryficzne, dz.cyt., s. 308. W apokryfie tym dodatkowo wskazano, że w jaskini tej „nigdy nie było światła”. Tamże. W Ewangelii Pseudo-Mateusza znajduje się również określenie „grota”. Por. tamże, s. 310. Mowa w niej o „stajni”, w której leżało Dzieciątko, nie jest ona wszakże miejscem Jego narodzin), Ewangelia Dzieciństwa Arabska (Ewangelia Dzieciństwa Arabska, w: Apokryfy Nowego Testamentu. Ewangelie apokryficzne, dz.cyt., s. 407) i Ewangelia Dzieciństwa Ormiańska (Ewangelia Dzieciństwa Ormiańska, w: Apokryfy Nowego Testamentu. Ewangelie apokryficzne, dz.cyt., s. 470).

15 Tak: Ewangelia gruzińska (Ewangelia gruzińska, w: Apokryfy Nowego Testamentu. Ewangelie apokryficzne, dz.cyt., s. 213) oraz Opowieść o magach (Opowieść o magach, w: Apokryfy Nowego Testamentu. Ewangelie apokryficzne, dz.cyt, s. 370-371. Wprawdzie Magowie przybyli jakiś czas po narodzeniu Jezusa, jednakże - zgodnie z tekstem apokryfu - „weszli do pomieszczenia, w którym urodził się [...] Przewodnik [Jezus]").

${ }^{16}$ Księga o narodzeniu Zbawiciela, o Maryi i o położnej, w: Apokryfy Nowego Testamentu. Ewangelie apokryficzne, dz.cyt., s. 319, 321. Sprzeczne miejsca narodzin podaje Ewangelia Barnaby (Ewangelia Barnaby, w: Apokryfy Nowego Testamentu. Ewangelie apokryficzne, dz.cyt., s. 251).

17 Cały świat nie pomieściłby ksiąg..., dz.cyt., s. 162. Motyw pustego domu występuje również w kaznodziejstwie (np. w Kazaniach gnieźnieńskich; Cały świat nie pomieściłby ksiag..., dz.cyt., s. 137). 
„[...] pod szopę pospolitą, w którą się ludzie schodzili czasu pluty i niepogody"18 [podkr. P.G.].

Autor tej późnośredniowiecznej przeróbki Meditationes vitae Christi pisze też - dosadnie - o „ubogiej śmierdzącej stajni”19.

Kasper Miaskowski bardzo chętnie używa występującego też w tłumaczeniu Opecia leksemu „szopa” ${ }^{20}$ (nawet przy opisie Bazyliki Narodzenia Pańskiego Rotuly, 2. Przemowa na rotuły, w. 54, występuje - sprzeczne wewnętrznie - określenie „szopa kamienna”), rzadziej mowa o "stajni” (Jasłeczka, w. 16) czy „stajence” (Rotuły, 2. Przemowa na rotuly, w. 139). Apokryficzne określenia „jaskinia” lub "grota” zostają zastąpione wyrazem „skała”, przy czym w dwóch miejscach (Jasłeczka, w. 34-36, Szopa zbawienna, w. 1-6) pojawia się dłuższy opis miejsca narodzin ${ }^{21}$. We fragmencie Jasłeczek znajduje się - zbieżny z tłumaczeniem Opecia - motyw miejsca będącego schronieniem ludzi w czasie złej pogody:

Nie w bogatej go szukajcie gospodzie [...]

ale gdzie oracz gwoli niepogodzie

twardą skałę wydrożył

i wierzch darnem położył [podkr. P.G.].

(Jasłeczka, w. 31, 34-36)

18 Baltazar Opeć, Żywot wszechmocnego Syna Bożego, Pana Jezu Krysta, Stworzyciela i Zbawiciela stworzenia wszytkiego: wedle ewanielist świętych, z rozmyślanim nabożnym doktorow Świętego Pisma ogarniony, Kraków 1522, k. List Xv. (Apokryficzna „książka cieszyła się ogromną poczytnością" (Cały świat nie pomieściłby ksiąg..., dz.cyt., s. 233). W samym tylko wieku XVI Żywot Pana Jezu Krysta wydawano pięciokrotnie (tamże).

19 Tamże, s. 252.

20 Wyraz „szopa” pojawia się w nazwie utworu Szopa zbawienna, w poszczególnych jego wersach (Szopa zbawienna, w. 7, 62, 131, 180), a także w: Przemowie na rotuły (w. 50, 85, 142) oraz rotułach: Klio (w. 33) i Poli<h>ymni, (w. 24). Poeta lokuje w „szopie" nie tylko narodziny Jezusa, ale również pokłon Mędrców (Szopa zbawienna, w. 131; Rotuly, 2. Przemowa na rotuły, w. 142; Rotuly, 9. Polihymnia, w. 24).

${ }^{21}$ Wyraz „skała” został użyty w: Jasłeczkach, w. 35; Szopie zbawiennej, w. 1, i Rotułach (Rotuły, 2. Przemowa na rotuły, w. 140). 
Zgodnie z Ewangelia Dzieciństwa Ormiańską, narodziny Jezusa miały miejsce w zimie ${ }^{22}$.

W Żywocie Pana Jezu Krysta wyraźnie zaakcentowano zimno przeszywające ubogo ubranego Chrystusa:

Patrzaj, iż się nie narodził w rozkoszy, ale [...] na gołej i twardej ziemi [...] zimy barzo ostrej: od zimna drżał, leżąc na ziemi gorzko płakał, nie mając, czym by się zagrzał ${ }^{23}$ [podkr. P.G.].

Miaskowski również sytuuje bożonarodzeniowe wydarzenia w zimie, co stanie się zresztą typowe dla polskiej tradycji: („[...] cicha zimie szopa”, IV. Szopa zbawienna, w. 7, „ostry wiatr wieje”, III. Jesłeczka, w. 39). Małe ciało Jezusa położone w „kamiennym” (Rotuły, 2. Przemowa na rotuły, w. 149) żłobie przejmuje ziąb:

${ }^{22}$ Ewangelia Dzieciństwa Ormiańska, w: Apokryfy Nowego Testamentu. Ewangelie apokryficzne, dz.cyt., s. 470.

${ }^{23}$ Cały świat nie pomieściłby ksiag..., dz.cyt., s. 252. W innym miejscu translacji Opecia mowa o „gołej i ostrej” ziemi (tamże). W „zimie barzo ostrej” umiejscawia też akcję bożonarodzeniowych wydarzeń autor średniowiecznego wiersza Dziecię najmilejsze, proszę Cię, nie płaczy, dołączonego do wydań Żywota Pana Jezu Krysta (Średniowieczna pieśń religijna polska, oprac. Mirosław Korolko, Wrocław 1980, s. 119). Mirosław Korolko zaznacza, że utwór jest pierwszym kolędowym tekstem polskim lokującym akcję betlejemskich wydarzeń w zimie (tamże). W wielu innych tekstach mowa o zimnie, które musiał cierpieć leżący na ziemi nowonarodzony Jezus; zziębniętego Syna Bożego najczęściej ogrzewają zwierzęta. Por. m.in. kolędy Witaj Jezu malutki, w. 41-42; O duszo moja, oto miłość Twoja, w. 9-11; Pódźmy do jasłek nowych Jezusa miłego, passim (Numeracja wersów pochodzi $\mathrm{z}$ tomu Kolędy polskie. Średniowiecze i wiek XVI, oprac. Stefan Nieznanowski, Juliusz Nowak-Dłużewski, Warszawa 1966, s. [kolejno] 37, 44-45, 79-83). Dłuższy opis zimowej scenerii zawiera utwór wchodzący w skład Wirydarza Stanisława Grochowskiego (8. Pożałowania rozmaitych doległości dziecięcych, I. Ubóstwo i niewczas przy narodzeniu, w. 11-16). W wielu utworach kustosza kruszwickiego mowa o Dziecięciu płaczącym z zimna (m.in. w: 1. Parafrazy, III. Córy syjońskie do Dziecięcia Pana Jezusa, w. 10; 4. Płacz i narzekanie dziecięce, III, Poeta, w. 15). Numery wersów cytowane są za wydaniem: Stanisław Grochowski, Wirydarz abo kwiatki rymów duchownych o Dziecięciu Panu Jezusie, oprac. Justyna Dąbkowska, Warszawa 1997. 
[...] pod żłobem drożonym, kędy noworodne członeczki położono w zimna niepogodne, jeden jęczy od skruchy za grzech popełniony [... $]^{24}$ [podkr. P.G.].

(Przemowa na rotuly, w. 59-60)

Niektóre fragmenty poezji Miaskowskiego (subtelnie) przywodzą na myśl obecny w Żywocie Pana Jezu Krysta motyw Dzieciątka leżącego na ziemi ${ }^{25}$. Na przykład w Przemowie na rotuły przychodzący do szopy pasterze:

[...] padszy na oblicze, całują tę ziemię,

która naprzód witała wieczne w ciele Plemię [...] [podkr. P.G.].

(Rotuly, 2. Przemowa na rotuly, w. 141-144)

Kamienne podłoże, na którym leży nowonarodzony Jezus, jest w ikonografii średniowiecznej (i późniejszej) symbolem Jego ofiary: krwawej (męki) lub bezkrwawej (Eucharystii) ${ }^{26}$. Analogicznie, posadzka lub kamienny żłób mogą oznaczać grób lub ołtarz ${ }^{27}$. Przedstawienie leżącego na ziemi Jezusa wiąże się też w ikonografii z przekazywaną przez apokryfy i inne źródła, zwłaszcza Objawienia św. Brygidy, informacją o bezbolesnym rozwiązaniu Maryi ${ }^{28}$.

Zimowy koloryt bożonarodzeniowej poezji Miaskowskiego można równie dobrze łączyć z innymi niż apokryficzne czynnikami (np.

\footnotetext{
24 Informacja o żłobie „wydrożonym” pojawia się też w wierszu Na zaczynanie Nowego Roku (Wiersze na Boże Narodzenie, 8. Na zaczynanie Nowego Roku, w. 36). 25 Zob. też Rotuły, 3. Klio, w. 25-28.

26 Por. Urszula M. Mazurczak, Komentarz ikonograficzny, w: Gdy Jezus narodził się w Betlejem, dz.cyt., s. 138-139, 193, 197; Jutta Seibert, Leksykon sztuki chrześcijańskiej. Tematy, postacie symbole, Kielce 2007, s. 216-218; Ryszard Montusiewicz, Prefiguracja męki i adoracja Dzieciątka w utworach kolędowych Kaspra Twardowskiego. Próba interpretacji ikonograficznej, „Roczniki Humanistyczne” 32 (1984), z. 1, s. 122-123. 27 Por. Ryszard Montusiewicz, dz.cyt., s. 122-123; Por. Urszula M. Mazurczak, dz.cyt., s. 197. Liryka poety pełna jest odniesień eucharystycznych. Jezus leżący w żłobie nazywany jest "Chlebem” (por. Szopa zbawienna, w. 12; Wiersze na Boże Narodzenie, 8. Na zaczynanie Nowego Roku, w. 41-42).

28 Jutta Seibert, dz.cyt., s. 218.
} 
terminem świąt). Smogorzewska poezja wykazuje jednak pewien związek z tłumaczeniem Opecia we fragmencie podkreślającym ubóstwo Jezusa ${ }^{29}$. W medytacyjnej części rozdziału $O$ narodzeniu autor translacji (powołując się na słowa św. Bernarda) zachęca do radości ubogich i kieruje upomnienie pod adresem bogatych ${ }^{30}$ :

Tenże święty Biernat mówi [...]: [...] Weselcie sie a bądźcie z tego pocieszeni wszytcy krześcijani, a zwłaszcza ubodzy, którzyście dla Krystusowej miłości tym światem obłudnym wzgardzili, a żywot ubogi dobrowolnie na się wzięli, abyście drogą ciasnego żywota ostrego tym wolniej za Panem Jezusem poszli. Z czegoż się wesel<i>cie, o ludzie bogaci, co legacie w rozkosznej łożnicy, gdyż ci Krol nad krolmi w swojem narodzeniu wolał uczcić leganie ostre, ubogie niźli wasze miękkie i bogate? ${ }^{31}$.

Analogicznie, biedne otoczenie Zbawiciela zestawia z zamożnością mieszkańców Jerozolimy Miaskowski:

\section{[...] I żłób, i ostre płaty ganią wczas i dom bogaty.}

Tu z ubóstwem włóż na wagę

pompę, stroje i powagę:

rzeczesz, ciężkie że tłómoki

na dół ciągną; to - w obłoki

\section{Bogate zaś po wieczerzy,}

patrz, jako sen wszystkie dzierży

w miękkim pierzu, a nie dbają,

że pogłówne w skrzyniach mają [podkr. P.G.].

(Szopa zbawienna, w. 19-28)

\footnotetext{
29 Akcentowanie ubogich narodzin Jezusa było cechą charakterystyczną utworów powstałych w nurcie duchowości franciszkańskiej (Por. Alicja Szulc, «Homo religiosus» późnego średniowiecza. Bernardyński model religijności masowej, Poznań 2007, s. 192; Ryszard Montusiewicz, dz.cyt., s. 130-131.

30 Analogiczny fragment znajduje się w Meditationes vitae Christi. Zob. Cały świat nie pomieściłby ksiag..., dz.cyt., s. 233. Pseudo-Bonawentura, Meditationes vitae Christi, Strassburg 1496, k. VIIv.

31 Cały świat nie pomieściłby ksiąg..., dz.cyt., s. 253.
} 
W obu fragmentach niedostatek Jezusa daje asumpt do refleksji nad materialnym i duchowym ubóstwem człowieka ${ }^{32}$. Porzucenie bogactw doczesnych pozwala pozbyć się niepotrzebnego balastu i daje wolność - mogą się nią cieszyć ubodzy adresaci słów św. Bernarda; powinni się do niej skłonić odbiorcy smogorzewskiej poezji. Pouczenie bezpośrednio skierowane do zamożnych zostaje zastąpione narracją, przeniesioną w palestyńskie (a ściślej - w jerozolimskie) realia ${ }^{33}$. Fragmenty pokrewne dziełu Opecia przeplatają się $\mathrm{z}$ aluzjami do ewangelii ${ }^{34}$. W przytoczonych ustępach widoczne są pewne zbieżności leksykalne (m.in. antonimiczne przymiotniki: „ostry” - „miękki”). Na uwagę zasługuje też fragment wiersza $\mathrm{Na}$ zaczynanie Nowego Roku, w którym poeta nazywa żłób Jezusa „zimną wielkiego Króla łożnicą" (Wiersze na Boże Narodzenie, 8. Na zaczynanie Nowego Roku, w. 5).

Przy żłobie Jezusa - tradycyjnie - znajdują się bydlęta:

Bo kędy wieczne kwili Słowo w żłobie, z osłem ledwie wół grzeje, co tak ostry wiatr wieje ${ }^{35}$.

(Jasłeczka, w. 37-39).

Figury wołu i osła stanowią od IV wieku po dziś dzień stały składnik bożonarodzeniowej ikonografii ${ }^{36}$ i powszechnie znanych kolęd. Najdawniejsze realizacje tematu Bożego Narodzenia w sztuce wczesnochrześcijańskiej składały się z trzech składników

\footnotetext{
32 Fragmenty kontrastujące ubóstwo Jezusa $\mathrm{z}$ bogactwem zamożnych pojawiają się też w innych utworach bożonarodzeniowych Miaskowskiego (Por. Jasłeczka, w. 31-36; Wiersze na Boże Narodzenie, 8. Na zaczynanie Nowego Roku, w. 13-14, 37-40).

33 Świadczy o tym dalszy ciąg utworu (Por. Szopa zbawienna, w. 29-36).

$34 \mathrm{~W}$ przytoczonym fragmencie można doszukiwać się odniesień do: przypowieści o „bezmyślnym bogaczu” (Łk 12,13-21), opowieści o bogatym młodzieńcu (Mt 19,1622) i dialogu Jezusa z uczniami po odejściu zamożnego rozmówcy (Mt 19,23-30).

35 Por fragment Żywota Pana Jezu Krysta: „Wół też i osieł [...] przez swe nozdrza dychając, Syna Bożego zziębniętego parą swą zagrzewali” (Cały świat nie pomieściłby ksiag..., dz.cyt., s. 252).

${ }^{36}$ Jutta Steibert, dz.cyt., s. 216.
} 
kompozycyjnych: wyobrażenia Jezusa w żłóbku, pasterzy oraz właśnie - wołu i osła ${ }^{37}$. Widzimy te zwierzęta obok Nowonarodzonego na fragmencie rzymskiego sarkofagu, datowanym na $343 \mathrm{rok}^{38}$, o zwierzętach w stajence wielokrotnie pisali też Ojcowie Kościoła ${ }^{39}$ oraz twórcy apokryfów właściwych, np. pochodzącej z VI wieku Ewangelii Pseudo-Mateusza ${ }^{40}$ :

[Maryja] [...] złożyła Dzieciątko w żłobie, a wół i osioł przyklękając, oddali mu pokłon. I wypełniło się to, co zostało powiedziane przez proroka Izajasza: „Poznał wół Pana swego i osioł żłób Pana swego”. Zwierzęta otoczyły Dzieciątko i wielbiły je nieustannie. Wtedy wypełniły się słowa proroka Habakuka: „Objawisz się w pośrodku zwierzą" ${ }^{31}$.

37 Piotr P. Maniurka, Boże Narodzenie, w: Encyklopedia katolicka, t. 2, red. Edward Gigilewicz, Lublin 1976, s. 743; Jutta Seibert, dz.cyt., s. 216.

38 Max Schmid, Die Darstellung der Geburt Christi in der bildenden Kunst, Stuttgart 189o, s. 74; cyt. za: Joseph Ziegler, Ochs und Esel an der Krippe. Biblisch-patristische Erwägungen zu Is 1,3 und Hab 3,2 (LXX), „Münchener Theologische Zeitschrift” 3 (1952), s. 387.

39 Joseph Ziegler, dz.cyt., s. 390-391. Zgodnie z ustaleniami badacza: wół i osioł pojawiają się zarówno w greckich, jak i łacińskich pismach Ojców Kościoła. $\mathrm{O}$ zwierzętach w stajence mowa m.in. w dziełach: Klemensa z Aleksandrii, Chryzostoma, Cyryla z Aleksandrii, Orygenesa, Bazylego Wielkiego i Grzegorza z Nazjanzu. Na Zachodzie symbolikę wołu i osła przedstawili m.in.: św. Ambroży w Wykładzie Ewangelii wg św. Łukasza i św. Hieronim w Liście 108 do Eustachium. Św. Hieronim - zgodnie z grecką tradycją - łączy figury wołu i osła z proroctwami Izajasza (Iz 1,3). Zob. Hieronim, Epist. 108 (Epitaphium S. Paulae) PL 22, s. 884. Innym źródłem tradycji był werset z Księgi Habakuka w brzmieniu Septuaginty (Ha 3,2). Por. Ewangelia Pseudo-Mateusza, dz.cyt., s. 310. Warto dodać, że dalszy ciąg Izajaszowego proroctwa (Iz 1,3 ad finem) kontrastuje postawę zwierząt $\mathrm{z}$ „nierozumnością” Izraela: „Israël autem me non cognovit, et populus meus non intellexit" (Bibliorum sacrorum latinae versiones antiquae seu vetus Italica, Paris 1751, druk. Francisa Didota, s. 515).

40 Ewangelia Pseudo-Mateusza, w: Apokryfy Nowego Testamentu. Ewangelie apokryficzne, dz.cyt., s. 292.

${ }^{41}$ Tamże, s. 310. Autor apokryfu cytuje Księgę Izajasza (Iz 1,3) i grecką wersję Księgi Habakuka (Ha 3,2) (por. tamże). 
Podobnie hołd zwierząt opisują autorzy obcych i rodzimych tekstów apokryficznych (np. Rozmyślania przemyskiego ${ }^{42}$ ). W Żywocie Pana Jezu Krysta zwierzęta otrzymują dodatkowe zadanie - ogrzewania zziębniętego Jezusa:

Wół też i osieł, Boga znając, do jaśli przystąpili, jakoby zwierzęta rozumne, na kolana swoje poklęknęly, przez swe nozdrza dychając, Syna Bożego zziębniętego parą swą zagrzewali ${ }^{43}$ [podkr. P.G.].

O ile łatwo było wytłumaczyć pojawienie się przy żłobie osła (Święta Rodzina musiała mieć przecież jakiś środek transportu), o tyle obecność wołu nie była już tak oczywista. W Złotej legendzie przedstawiono ciekawy motyw wołu prowadzonego do Betlejem w celach handlowych:

[...] Józef wyjeżdżając z Betlejem, powiódł ze sobą wołu i osła: wołu może, aby go sprzedać i mieć $\mathrm{z}$ czego zapłacić denar spisu; osła niewątpliwie, by służył do jazdy świętej Dziewicy ${ }^{44}$ [podkr. P.G.].

Sugestia zawarta w Złotej legendzie uznana jest w Rozmyślaniu o żywocie Pana Jezusa za pewnik:

[...] Dziewica Maryja będęcy brzemienna siedziała na osiełku a wołu myślili przedać na strawę i na ine rzeczy i potrzeby ${ }^{45}$.

Nie wiadomo, czy i z ilu wyżej wymienionych tekstów apokryficznych korzystał Miaskowski ${ }^{46}$, pewne jest jednak, że zapleczem

\footnotetext{
42 Rozmyślanie o żywocie Pana Jezusa. Z rękopisu grecko-katolickiego kapituły przemyskiej, oprac. Aleksander Brückner, Kraków 1907, s. 60-61. „Poznały ta nierozumna zwierzęta swego stworzyciela” (tamże, s. 61). Por. Iz 1,3.

43 Cały świat nie pomieściłby ksiag..., dz.cyt., s. 252.

44 Jakub de Voragine, Złota legenda, oprac. Leopold Staff, Wrocław 1994, s. 55.

45 Rozmyślanie o żywocie Pana Jezusa..., dz.cyt., s. 58.

46 Złota legenda była swego czasu bardzo popularna (również na terenie Polski, por. np. Władysław Smoleń, «Rozmyślanie przemyskie» jako źródło ikonograficzne kwatery ofiarowania Maryi ołtarza mariackiego Wita Stwosza, „Pamiętnik Literacki” 51 (1960), z. 3, s. 127), istnieją też przesłanki, na podstawie których można wysunąć wniosek o „publicznym użyciu” Rozmyślania przemyskiego (por. tamże, s. 143).
} 
jego wyobraźni były popularne ikono- i logosfera (kolędy) ${ }^{47}$. We fragmencie Przemowy na rotuły pojawiają się więc prawie wszystkie apokryficzne informacje na temat wołu i osła (ogrzewanie Dzieciątka, sprzedaż bydlęcia, hołd zwierząt):

Po bokach zaś onego kamiennego żłobu para płynie gorąca nad Nim $\mathrm{z}$ bydląt obu które z sobą przywiódł był ociec domniemany (osieł dźwigał potrzeby, wół na czynsz przedany) te też przednie spuściwszy na ziemię kolana, chwaliły, bezrozumne, wcielonego Pana ${ }^{48}$.

(Rotuly, 2. Przemowa na rotuly, w. 149-150, 153-154)

Zachodni model ikonografii Bożego Narodzenia, ukształtowany dopiero w XIV i XV stuleciu ${ }^{49}$, eskponuje scenę adoracji Dziecięcia, kiedy to zgromadzone wokół żłóbka postaci składają Jezusowi po-

Popularność Żywota Pana Jezu Krysta (o której była już mowa wyżej) i rozmaite similia tekstowe między utworem Opecia a smogorzewską poezją pozwalają na przypuszczenie, że dzieło to było Miaskowskiemu znane.

${ }_{47}$ Motyw wołu i osła przewija się przez szereg staropolskich utworów kolędowych różnych wieków. Wystarczy przywołać choćby średniowieczne pieśni: Mesyasz, wierny Chrystus nasz (w. 7-8), Wesoły nam dzień nastat (w. 33-34), renesansową kolędę z Kancjonału Walentego z Brzozowa 1554 (np. Chwalmyż Boga Ojca Wszechmogącego, w. 55-57, czy późniejsze utwory z kancjonałów staniąteckich (Pan Jezus się nam narodził w mieście Betleem, w. 10-12; Nuż my dziś, krześcijani, w. 31-36). Numeracja wersów według wydania Kolędy polskie. Średniowiecze i wiek XVI, dz.cyt., s. [kolejno] 17, 120-121, 247, 247-248. Zob. też. Stefan Nieznanowski, Barokowe kolędy polskie, w: Necessitas et ars. Studia staropolskie dedykowane Profesorowi Januszowi Pelcowi, t. 1, red. Barbara Otwinowska, Warszawa 1993, s. 113-121.

${ }^{48} \mathrm{~W}$ tym fragmencie pobrzmiewa także tekst Izajaszowego proroctwa (Iz 1,3) „chwaliły, bezrozumne, wcielonego Pana”. Motyw ogrzewania Dziecięcia jest obecny także w rotułach (zob. Rotuły, 4. Euterpe, w. 7). Pokłon zwierząt pojawia się również w Szopie zbawiennej, w. 67-68. Wzmiankę o pozaewangelicznej proweniencji motywu wołu prowadzonego na sprzedaż zamieściła Alina Nowicka-Jeżowa w krytycznym wydaniu Zbioru rytmów: Alina Nowicka-Jeżowa, Objaśnienia, w: Kasper Miaskowski, Zbiór rytmów, dz.cyt., s. 389.

49 Ryszard Montusiewicz, dz.cyt., s. 122, Jutta Seibert, dz.cyt., s. 217-218. 
kłon $^{50}$. Klęczy więc przede wszystkim Maryja, postawę uwielbienia przyjmuje św. Józef, często też pojawiają się adorujący Jezusa aniołowie, zwierzęta, pasterze i Mędrcy ${ }^{51}$. Powstanie „Typu Adoracji Dzieciątka" łączy się nieraz z objawieniami św. Brygidy Szwedzkiej ${ }^{52}$. Na szczególną uwagę zasługują jednak konstatacje uczonych łączących początki zachodniego wzorca ikonograficznego z wywodzącym się z franciszkańskich kręgów dziełem Meditationes vitae Christi:

Autor Meditationes jako pierwszy nie przedstawił Maryi odpoczywającej po Narodzeniu Jezusa. Dziewica przyjmuje postawę klęczącą: „Tymczasem Matka, uklęknąwszy, uczciła go mówiąc: Dziękuję Ci Panie, Święty Ojcze, za to, że dałeś mi Twojego Syna. Adoruję Ciebie, wieczny Boże i adoruję Twojego Syna, który jest również moim Synem. Józef podobnie uczcił Dziecko i aniołowie z nieba przychodzili uklęknąć przed Nowonarodzonym ${ }^{53}$.

50 Ryszard Montusiewicz, dz.cyt., s. 122, Jutta Seibert, dz.cyt., s. 218.

51 Jutta Seibert, dz.cyt., s. 218, Ryszard Montusiewicz, dz.cyt., s. 122.

52 Por. Ryszard Montusiewicz, dz.cyt., s. 122. Wizja św. Brygidy przedstawia narodziny Jezusa bardzo plastycznie: „[...] nagle, w jednym momencie, urodziła Syna, od którego biło takie światło, do którego nie dało się porównać nawet słońca [...]. Jednocześnie widziałam owo wspaniałe Dzieciątko leżące w świetlistej poświacie nago na ziemi. Jego ciało było zupełnie czyste. Słyszałam też miły śpiew aniołów. Gdy Dziewica spostrzegła, że już urodziła, skłoniła głowę, złożyła ręce i pełna czci adorowała Dzieciątko" (cyt za: Jutta Seibert, dz.cyt., s. 218).

53 "The author of the Meditationes was the first to think of the Virgin of the Nativity otherwise than recumbent upon her bed. He visualized her kneeling before her Son. „Meanwhile the mother, having knelt, worshiped Him, saying «I thank Thee, Lord, Holy Father, because Thou hast given me Thy Son. I adore Thee, eternal God and I adore Thy Son, Who is also my Son». Joseph likewise worshiped the Child, and the angels of heaven came to kneel down before the newborn Babe" (Émile Mâle, Religious Art from the Twelfth to the Eighteenth Century, Princeton 1982, s. 103-104, tłum P. Głuszak. Tytuł oryginału: L’Art religieux du XIIe au XVIIIe Siècle). Podobnie: Jutta Seibert, dz.cyt., s. 218. Warto przypomnieć, że pokłon Maryi pojawia się już w (datowanej najpóźniej na V/VI w.) Księdze o narodzeniu Zbawiciela, o Maryi i o położnej: „Dzieweczka stojąc była wpatrzona w niebo i stała się jakby śnieżno biała. [....] Gdy zaś pojawiła się Światłość, złożyła pokłon temu, którego ujrzała, że Go wydała. Samo zaś Dzieciątko wielce zajaśniało wokół niczym słońce [...]” (Księga 
Według Émile’a Mâle’a, żywa wyobraźnia i wrażliwość autora utworu zainspirowała włoskich artystów do dokonania zmian w starym wzorcu ikonograficznym ${ }^{54}$. Przedstawienie Maryi klęczącej przed Jezusem (a nie - jak dotychczas - wypoczywającej po trudach porodu) związane jest z przeświadczeniem o bezbolesnych narodzinach Syna Bożego ${ }^{55}$, co miało być między innymi dowodem tego, że niepokalanie poczęta Maryja wolna była od „przekleństwa Ewy” (Rdz 3,16). Jezus miał wyjść z Maryi tak, jak światło przenikające kryształ (drogocenny kruszec symbolizował ciało Matki Boga) ${ }^{56}$. Ten typ ikonograficzny, a także nawiązująca do niego poezja związane były więc właśnie z upowszechniającym się przekonaniem o wolności Maryi od grzechu pierworodnego ${ }^{57}$.

Rozbudowany fragment opisujący narodziny Jezusa i pokłon Maryi znajduje się w polskiej przeróbce Meditationes vitae Christi:

o narodzeniu Zbawiciela, i o Maryi, i o położnej, w: Apokryfy Nowego Testamentu. Ewangelie apokryficzne, dz.cyt., s. 318, 323).

54 Tamże, s. 103.

55 Jutta Seibert, dz.cyt., s. 218.

56 Jak wskazuje Mirosława Hanusiewicz (dz.cyt., s. 242), przekonanie to znalazło swój wyraz w rotule Melpomene (Rotuły, 6. Melpomene, w. 5-6). Dziewicze i bezbolesne narodziny Jezusa porównywano w literaturze średniowiecznej do promieni świetlnych przenikających kryształ (tamże, s. 242-243). Światło często towarzyszyło narodzinom Jezusa w literaturze apokryficznej (Por. tamże, s. 243-244). Motyw ten pojawia się m.in. w: Protoewangelii Jakuba (Protoewangelia Jakuba, w: Apokryfy Nowego Testamentu. Ewangelie apokryficzne, dz.cyt., s. 284), Ewangelii Pseudo-Mateusza (Ewangelia Pseudo-Mateusza, w: Apokryfy Nowego Testamentu. Ewangelie apokryficzne, dz.cyt., s. 308-309), Ewangelii Dzieciństwa Arabskiej (Ewangelia Dzieciństwa Arabska, w: Apokryfy Nowego Testamentu. Ewangelie apokryficzne, dz.cyt., s. 407) czy Ewangelii Dzieciństwa Ormiańskiej (Ewangelia Dzieciństwa Ormiańska, w: Apokryfy Nowego Testamentu. Ewangelie apokryficzne, dz.cyt., s. 472-473). Występuje też w polskich tekstach apokryficznych, m.in. w Rozmyślaniu przemyskim (Rozmyślanie o żywocie Pana Jezusa..., dz.cyt., s. 6o). Mirosława Hanusiewicz pisze o obecności tego motywu w Przemowie na rotuły (dz.cyt., s. 243-244).

57 Na ten temat zob. Jan Fijałek, Nasza nauka krakowska o Niepokalanym Poczęciu N. P. Maryi w wiekach średnich, „Przegląd Polski” 1900, s. 420-285. 
[...] powstała Panna z wielkiej radości i dała się na modlitwę, a będąc w niewymownej słodkości porodziła Syna Bożego, nie mając żadnej boleści. A tak Syn Boży, [...] który jest jako kwiat nad słońce jaśniejszy [...] zakwitnąwszy na latorośli niskiej, to jest w żywocie Panny pokornej, wyszedł przez swe święte narodzenie z Maryjej [...] przez wszytkiej trudności. Gdy Panna k sobie przyszła, ujrzała dziecię, $[. .$.$] płaczące słyszała, też i widziała anioły śpiewające.$ Poklęknąwszy nabożnie mu chwałę dała, Bogu Ojcu Niebieskiemu dziękowała, mówiąc: „O, Boże Wszechmocny, niewymowne dawam dzięki twej miłości albo dobroci, iżeś mi twego Syna dał i matką mie jego uziałał [...]" ${ }^{58}$ [podkr. P.G.].

W poezji Kaspra Miaskowskiego, podobnie jak w wyżej przywołanych tekstach, Maryja przyjmuje postawę klęczącą. Jak na obrazach przedstawiających scenę Bożego Narodzenia pochyla się nad Jezusem, składając dłonie w modlitewnym geście. Widok opisany jest z perspektywy przybyszów:

Tam padszy na oblicze, całują [...] ziemię [...], a dźwigając głowy swe ujźrzą po tej stronie Panienkę zlotowlosą, co słoniowe dłonie klęcząc nad swym podnosi dawno Niemowiątkiem, nad tymże mąż szedziwy zdumial się Dzieciątkiem [podkr. P.G.].

(Rotuly, 2. Przemowa na rotuly, w. 143, 145-147) $)^{59}$

Matka Boża adoruje Syna nieustannie - określenie „dawno” sugeruje długi czas trwania czynności. Złote włosy są jednym z przejawów wewnętrznego piękna Maryi ${ }^{60}$.

\footnotetext{
58 Cały świat nie pomieściłby ksiag..., dz.cyt., s. 251.

59 Analogiczny obraz znajduje się w Szopie zbawiennej (Szopa zbawienna, w. 61-64).

${ }^{60}$ Por. Mirosława Hanusiewicz, dz.cyt., s. 240-241. Rozmyślanie przemyskie przekazuje informację o „rusych albo żółtych” włosach Maryi (Rozmyślanie o żywocie Pana Jezusa..., dz.cyt. s. 33). „Zainteresowanie” Kaspra Miaskowskiego „fizyczną urodą matki i dziecka” było przedmiotem rozważań Stefana Nieznanowskiego, O poezji Kaspra Miaskowskiego..., dz.cyt., s. 36-37), który zaznaczył, że „Opisy [...]
} 
Obok „Panienki” znajduje się święty Józef, który - zgodnie z pozakanoniczną tradycją - jest starszym człowiekiem („mąż szedziwy”, Rotuly, 2. Przemowa na rotuly, w. 147) ${ }^{61}$. Cechę tę wymienia już Protoewangelia Jakuba ${ }^{62}$. Starość Józefa miała niejako gwarantować dziewictwo Maryi. Starożytne teksty pozakanoniczne wplatają informację o podeszłym wieku Jezusowego opiekuna w tok opowiadania o wyborze męża dla świątobliwej Panny ${ }^{63}$. Nie inaczej jest z polskimi tekstami okołoapokryficznymi. Rozmyślanie przemyskie cytuje słowa namawianego do małżeństwa Józefa:

Ja nędzny, wszego luda niszy nie jestem dostojen poruszyć tak świętego dziewictwa, bowim ja już przyszedł w stare lata, nie jest podobno, iżbych tako młodą i tako dostojną dziwkę poją ${ }^{64}$ [podkr. P.G.].

Niemal identyczny fragment znajduje się w Żywocie Pana Jezu Krysta ${ }^{65}$ (Tadeusz Dobrzeniecki wykazał zależność obu tekstów od Vita beate virginis Marie rythmica ${ }^{66}$ ).

Podobnie jak Maryja, święty Józef trwa w postawie adoracji:

urody [Maryi i Jezusa] są skombinowaniem przekazu apokryficznego z współczesną ikonografią tematu" (tamże, s. 36).

${ }^{61}$ Por. Alina Nowicka-Jeżowa, Wstęp, w: Kasper Miaskowski, Zbiór rytmów, dz.cyt., s. 389.

${ }^{62}$ Protoewangelia Jakuba, w: Apokryfy Nowego Testamentu. Ewangelie apokryficzne, dz.cyt., s. 275. Tekst znany jest w świecie chrześcijańskim już od IV wieku (tamże, s. 267). Marek Starowieyski wskazuje, że Protoewangelia Jakuba „stała się [...] podstawą do powstającej ikonografii chrześcijańskiej Wschodu i Zachodu [...]” (tamże). O późnym wieku Józefa wspominają też: Ewangelia Pseudo-Mateusza (tamże, s. 304); Księga o narodzeniu świętej Maryi (tamże, s. 338) i Ewangelia Dzieciństwa Ormiańska (tamże, s. 451). W ikonografii częste są przedstawienia Józefa-starca.

63 Tak we wszystkich pismach apokryficznych wymienionych w poprzednim przypisie.

${ }^{64}$ Rozmyślanie o żywocie Pana Jezusa..., dz.cyt., s. 41.

65 „Ja nędzny wszego ludu niższy, nie jestem dostojen poruszyć tako świętego dziewictwa, bom ja już przyszedł w stare lata, a dla tego nie jest podobno, abych tako młodą i tako dostojną dziewicę pojął”. Baltazar Opeć, dz.cyt., k. List IIIIv.

${ }^{66}$ Tadeusz Dobrzeniecki, Łacińskie źródła "Rozmyślania przemyskiego», w: Średniowiecze. Studia o kulturze, t. 4, red. Julian Lewański, Wrocław 1969, s. 260, 269. 
Ściągnąwszy i Józef dłonie, w niskim dał mu cześć ukłonie [...].

(Szopa zbawienna, w. 65-66)

Z przytoczonego wcześniej fragmentu Przemowy na rotuły (w. 148), opisującego „zdumienie” Józefa, wiadomo, że jest to modlitwa uwielbienia. Poezja Miaskowskiego zdradza w tym zakresie łączność z rodzimą tradycją apokryficzną, wyrażoną w Rozmyślaniu przemyskim ${ }^{67}$ :

[...] Józef wrócił sie, nalazł dziewicę Maryję już porodziwszy Syna Boga w Trójcy jedynego, natychmiast padnął na swe kolana, dał chwałę Dzieciątku i chwalił Boga wszechmogącego w Jego wielikiej mocy ${ }^{68}$.

„Zdumienie” opiekuna Maryi zostało wyrażone w - przekazanym przez Rozmyślanie przemyskie - kantyku Józefa (nazwanym Pieniem Józefowym $)^{69}$, w którym „mąż szedziwy” przywołuje starotestamentowe prefiguracje Chrystusa ${ }^{70}$ :

Toć jest to miłe dzieciątko, święte, któreż widziemy świętych prorokow [...], toć on wąż [...] miedziany na puszczy, ktorego Mojżesz kazał na krzyżu powyszyć [...] to jest ona rosa [...], to jest, któraż zmaczała odzienie Jedeonowo; [...] to jest kwiat jen zakwitł zamacice (!) Jesse, jen ma być zbawiciel i odkupiciel wszego świata. Toć jest manna schowana w korabiu zakonnym; [...] to jest dziecie, onim że wszyscy prorocy przepowiedali [....]. To jest ono dziecie, onim że Izajasz prorokowal, iże dziewica pocznie i porodzi Syna Boga w Trójcy jedynego ${ }^{71}$.

\footnotetext{
${ }^{67}$ Autor polskiej translacji Meditationes vitae Christi nie wspomina o tym wydarzeniu, choć w oryginale znajduje się wzmianka na ten temat (por. przytoczony wyżej fragment rozprawy Èmile’a Mâle’a).

68 Rozmyślanie o żywocie Pana Jezusa..., dz.cyt., s. 60.

69 Motywy pokłonu i „pienia” Józefa zostały (najprawdopodobniej) zaczerpnięte z tradycji okołoapokryficznej (w dostępnych w wydaniu Marka Starowieyskiego apokryfach właściwych nie ma wzmianki o klęczącym i uwielbiającym Dzieciątko opiekunie).

70 Tadeusz Dobrzeniecki, dz.cyt., s. 289. Autor zaznacza, że prefiguracje pojawiają się w drugiej części kantyku.

${ }^{71}$ Rozmyślanie o żywocie Pana Jezusa..., dz.cyt., s. 61-62.
} 
Wszystkie te motywy pojawiają się w smogorzewskiej poezji (utwory bożonarodzeniowe Kaspra Miaskowskiego pełne są dowodów na to, że Jezus przyszedł „wypełnić Zakon” i „Proroki” Mt 5,17 ${ }^{72}$ ), nigdy jednak nie wygłasza ich święty Józef. Dwukrotnie natomiast mowę wyrażającą radość ze ziszczenia się spełnionych przepowiedni i zrealizowania prefiguracji wkłada poeta w usta pasterzy (Szopa zbawienna, w. 73-112; Przemowa na rotuly, w. 163-172, 175-183 $3^{73}$ ). W Szopie zbawiennej entuzjastycznie wołają:

Co śpiewają nam prorocy,

to już widzą nasze oczy.

Zyściły się twoje karty,

mężu ostrą piłą tarty.

(Szopa zbawienna, w. 73-76)

Mąż „ostrą piłą tarty” to, jak się okazuje, Izajasz ${ }^{74}$. Pasterze, podobnie jak Józef, obwieszczają, że narodzenie Jezusa jest wypełnieniem słów zapisanych na kartach księgi proroka przeciętego ostrą piłą Dochodzi tu do głosu pozakanoniczna tradycja, mająca - być może swoje źródło jeszcze w apokryfach żydowskich, zgodnie z którą Izajasz

\footnotetext{
72 Biblia w przekładzie księdza Jakuba Wujka, oprac. Janusz Frankowski, Warszawa 1999. Na obecność „prefiguracyj Chrystusa” w Przemowie na rotuły wskazywał Stefan Nieznanowski, O poezji Kaspra Miaskowskiego..., dz.cyt., s. 41). O kontekstualności poezji pisała też Alina Nowicka-Jeżowa (Wstęp, w: dz.cyt., s. 9). W tym zakresie poezja bożonarodzeniowa Kaspra Miaskowskiego ściśle łączy się z przesłaniem Ewangelii wg św. Mateusza. To właśnie ta, skierowana do Żydów, ewangelia najsilniej podkreślała fakt, że „[...] w osobie, w życiu, w czynach i w nauce Jezusa urzeczywistniły się wszystkie proroctwa Nowego Testamentu” (Wstęp do Ewangelii wg św. Mateusza, w: Pismo Święte Starego i Nowego Testamentu [Biblia Tysiąclecia], oprac. Zespół Biblistów Polskich z inicjatywy Benedyktynów Tynieckich, s. 1124). 73 W wersach 163-172 poeta przytacza pochwalne pienia pasterzy w mowie zależnej, w wersach 175-183 w mowie niezależnej.

74 Alina Nowicka-Jeżowa, Objaśnienia, w: Kasper Miaskowski, Zbiór rytmów, dz.cyt., s. 386.

75 Alina Nowicka-Jeżowa łączy fragment utworu raczej z ustępem biblijnym, zawierającym przepowiednię pomsty Boga nad Asyrią (Iz 10,15) (tamże).
} 
zginął męczeńską śmiercią za panowania króla Manassesa ${ }^{76}$. Tak o tym mówi etiopska wersja apokryficznego Wniebowstąpienia Izajasza:

Z powodu tych widzeń Beliar rozgniewał się na Izajasza i osiedlił się w sercu Manassesa, a [ten] przeciął Izajasza drewnianą piłą. Podczas gdy Izajasz był przecinany, obok stał jego oskarżyciel Bekira, stali wszyscy fałszywi prorocy ciesząc się i wyśmiewając Izajasza. Izajasz zaś w czasie piłowania nie krzyczał, ani nie zapłakał, lecz jego usta mówiły do Ducha Świętego, aż został rozcięty na dwoje ${ }^{77}$.

Wprawdzie piła jest głównym atrybutem ikonograficznym świętego Szymona, istnieją jednak przedstawienia, na których narzędzie tortur symbolizuje męczeńską śmierć starotestamentalnego profety ${ }^{78}$. Za przykład może posłużyć lewe skrzydło tryptyku Złożenie do grobu autorstwa szesnastowiecznego malarza Maartena van Heemskercka ${ }^{79}$. Samo męczeństwo Izajasza przedstawiają liczne iluminacje średniowiecznych manuskryptów. Jedna z nich dekoruje francuskie tłumaczenie Historia scholastica Piotra Comestora (przedstawia dwóch oprawców przecinających piłą głowę proroka $)^{80}$.

Pasterze oddają chwałę Jezusowi, przyjmując - jak inne postaci bożonarodzeniowej historii - postawę klęczącą (Jasłeczka, w. 40-42; Szopa zbawienna, w. 89-90) ${ }^{81}$. Razem z nimi przed żłóbkiem „klęka” poeta:

\footnotetext{
76 Hipotezę o żydowskiej proweniencji motywu przywołuje Marek Starowieyski, choć sam optuje raczej za judeochrześcijańskim pochodzeniem całego apokryfu (Marek Starowieyski, Apokryfy Nowego Testamentu. Listy i apokalipsy chrześcijańskie, Kraków 2002, s. 134-135).

77 Wniebowstapienie Izajasza, w: Apokryfy Nowego Testamentu. Listy i apokalipsy chrześcijańskie, dz.cyt., s. 147-148. Wersja grecka apokryfu zachowała się jedynie w szczątkowej formie (tamże, s. 135).

78 Jutta Seibert, dz.cyt., s. 126, 311.

79 Królewskie Muzeum Sztuk Pięknych w Brukseli, 1559-1560.

80 Jean Bondol, Męczeństwo Izajasza, ilustracja do: Piotr Comestor, Bible historiale complétée, tłum. Guyart des Moulins (rkps ok. 1372), k. 355v. Manuskrypt znajduje się aktualnie w Museum Meermanno-Westrenianum w Hadze [sygnatura: Den Haag, MMW 10 B 23].

81 W poezji Miaskowskiego pasterze, wchodząc do stajenki, zastają klęczących przed Jezusem wołu i osła (Jasłeczka, w. 37-39 - tu wypowiedź anioła antycypuje
} 
My też, padszy na kolana, Wzywamy Cię jako Pana, A Ty przyjmi hołd nasz pierwszy upominek prostych wierszy.

(Szopa zbawienna, w. 89-92)

Opowieść Miaskowskiego o pokłonie pasterzy zawiera dwa elementy o proweniencji apokryficznej: górzyste ukształtowanie terenu ${ }^{82}$, na którym wypasali owce pasterze, i gwiazdę prowadzącą zarówno Mędrców, jak i prostaczków. Informacja o pobycie pasterzy w górach została najwyraźniej przedstawiona w Księdze o narodzeniu Zbawiciela, o Maryi i o położnej ${ }^{83}$ :

Zeszłej nocy siedzieliśmy na górze czuwając, a księżyc świecił, jakby w dzień pogodny. My zaś, wedle zwyczaju strzegliśmy owiec naszych od złodziei i wilków. Gdy [...] rozmawialiśmy między sobą, raptem pojawił się przed nami wielki i potężny mąż ${ }^{84}$ [podkr. P.G.].

wspomniane zdarzenie; Szopa zbawienna, w. 61-68; Przemowa na rotuły, w. 143154). Schemat ten zaczerpnięty został - być może (bezpośrednio lub pośrednio) - z Rozmyślania przemyskiego, w którym motyw ten został wyakcentowany: „[pasterze] osłowi z wołem, kiedy Jemu [Dziecięciu] chwałę dawali, nasilnie się dziwowali [...]” (Rozmyślanie o żywocie Pana Jezusa..., dz.cyt., s. 63).

${ }^{82}$ Tłumaczenie Jakuba Wujka, podobnie jak Wulgata („Et pastores erant in regione eadem vigilantes, et custodientes vigilias noctis super gregem suum" (Lc 2,8) podaje jedynie wzmiankę o „tejże krainie”. Cyt. za: Biblia sacra Veteris et Novi Testamenti. Secundum editionem vulgatam, t. 2, Basileae 1591, druk. Thomasa Guarina, s. 55.

${ }^{83}$ Ewangelia gruzińska wskazuje na miejsce „W pobliżu [...] skały” (Ewangelia gruzińska, oprac. Marek Starowieyski, w: Apokryfy Nowego Testamentu. Ewangelie apokryficzne, dz.cyt., s. 213). Informacja ta wiąże się jednak z umiejscowieniem narodzin Jezusa w grocie. W Ewangelii Dzieciństwa Ormiańskiej pasterze wypasają owce „w górach i w dolinach”, noc Bożego Narodzenia jednak (jak każdą inną noc) spędzają w owczarni (Ewangelia Dzieciństwa Ormiańska, w: Apokryfy Nowego Testamentu. Ewangelie apokryficzne, dz.cyt., s. 474.

${ }^{84}$ Księga o narodzeniu Zbawiciela, o Maryi i o położnej, oprac. Marek Starowieyski, w: Apokryfy Nowego Testamentu. Ewangelie apokryficzne, dz.cyt., s. 325. 
Górzysty krajobraz nie pojawia się ani w Rozmyślaniu przemyskim, ani w Żywocie Pana Jezu Krysta. Najprawdopodobniej więc poeta zaczerpnął ten motyw ze źródeł pozaliterackich, np. z ikonografii ${ }^{85}$. W Przemowie na rotuły znajduje się fragment kontynuujący tradycję obecną w wyżej przywołanym apokryfie właściwym:

A pod ten czas nad miastem, nie wierząc czeladzi [...] rozpuścili stada swe przestronnym odłogiem, psy na smyczy w obrożach dzierżąc jedną dłonią, żeby mieć na wilka gotową pogonią [podkr. P.G.].

(Rotuly, 2. Przemowa na rotuly, w. 96-100)

Słowa „nad miastem” sugerują wysokie położenie miejsca, w którym czuwali pasterze. Zbieżność opisów dotycząca ochrony przed wilkami może być dziełem przypadku. Autor tekstu natchnionego pisze o pasterzach „czujących” $i$,strzegących nocne straże nad trzodą swoją" (Łk 2,8). Łatwo więc z tego wyprowadzić wniosek, że owce musiały być chronione przed dziką zwierzyną. Zbliżony do powyższego fragment znajduje się w dalszych wersach Przemowy na rotuly:

Bieżą tedy z weselem na góry zaś znowu

Dojrzeć, by tam samopas nie wziął źwierz obłowu [podkr. P.G.].

(Przemowa na rotuly, w. 187-188)

\footnotetext{
85 Artyści często przedstawiają pasterzy jako prostych i ubogich ludzi na tle rodzimej, regionalnej scenerii (Urszula M. Mazurczak, dz.cyt., s. 203). Przykładem ikonograficznej realizacji motywu mogą być ilustracje do średniowiecznych manuskryptów np. iluminacje do Les Belles Heures (Bracia Limburgowie, Zwiastowanie pasterzom, ilustracja do: autor anonimowy, Les Belles Heures du Duc de Berry, Paryż 1408-1409, k. 52r.; eksponat znajduje się aktualnie w Metropolitan Museum of Art w Nowym Jorku) i znane renesansowe dzieła sztuki (np. Domenico Ghirlandaio, Adoracja pasterzy, kościół Świętej Trójcy we Florencji, 1485; Hugo van der Goes, Pokłon pasterzy [obraz centralny tzw. Tryptyku Portinarich], Galeria Uffizi we Florencji, 1476-1478).
} 
Po oddaniu czci Dzieciątku pasterze wracają do zajęć, które opuścili (zostawiając stado samopas) ufni w Bożą opiekę. Paralelny fragment znajduje się w Żywocie Pana Jezu Krysta:

[...] a tak z weselim do trzód swoich sie wrócili ${ }^{86}$.

Znany jest ikonograficzny motyw anioła, który pilnuje pasącego się na górze stada ${ }^{87}$.

Pasterze po wejściu do miasta łatwo trafili do betlejemskiej stajenki, gdyż na niebie pojawiła się gwiazda:

A wpadszy w głuche miasto w nocny czas głęboki, drugi cud im pokażą wesołe obłoki, bo ogień roznieciwszy nowa gwiazda nowy [...] wiodąc i jezdne wprzód, i pozad sługi, promieniem [...] ubogiej stajenki sięgała [...].

(V. Rotuly, 2. Przemowa na rotuły, w. 131-133, 138-139)

O gwieździe ogromnych rozmiarów w kontekście uwielbienia składanego Bogu przez pasterzy pisze autor Ewangelii Pseudo-Mateusza ${ }^{88}$. W Rozmyślaniu przemyskim informację o tym, że prości ludzie ujrzeli nowe ciało niebieskie, wyrażono expressis verbis:

Pasterze poczęli między sobą mówić rzekąc: podźmy do Betleem, uźrzemy to Dziecię, któreż nam anioł powiedział [...]. Przyszedszy do Betleem, ujrzeli nową gwiazdę światłą $[\ldots]^{89}$.

\footnotetext{
${ }^{86}$ Baltazar Opeć, dz.cyt., k. List XIv.

87 Tak m.in. na wspomnianym obrazie Domenica Ghirlandaio.

88 „Aniołowie oznajmili im [pasterzom], że narodził się Zbawiciel ludzi, Chrystus Pan, przez którego przyjdzie zbawienie Izraela. A od wieczora aż do rana świeciła gwiazda o wielkości dotąd nie spotykanej. Owa gwiazda zwiastowała narodzenie Chrystusa, który wypełni obietnice nie tylko wobec Izraela, lecz także wobec wszystkich narodów" (Ewangelia Pseudo-Mateusza, w: Apokryfy Nowego Testamentu. Ewangelie apokryficzne, dz.cyt., s. 310). Motyw jest obecny również w Ewangelii gruzińskiej, Utworach z Cyklu o Magach: Pokłonie Magów i Korespondencji Longinusa z Augustem, oraz Ewangelii Dzieciństwa Ormiańskiej.

89 Rozmyślanie o żywocie Pana Jezusa..., dz.cyt., s. 62.
} 
Gwiazda wiedzie do „stajenki” zarówno pasterzy, jak i królów („[...] jezdne wprzód, i pozad sługi”, V. Rotuły, 2. Przemowa na rotuły, w. 138). W tekście Jasłeczek nadprzyrodzony obiekt niebieski jest zarazem inspiracją i przewodnikiem:

Co to za gwiazda tak bystrych promieni

od zorze aż różan<éj>

i głos ten niespodziany,

że orszak gości wielkich się nie leni

witać Króla [...]? [podkr. P.G.]

$\left(\right.$ Jasłeczka, w. 67-71) ${ }^{90}$.

Ów „głos [...] niespodziany” to niekoniecznie głos śpiewających Jezusowi aniołów. W przytoczonym ustępie znajduje wyraz tradycja wywodząca się m.in. ze starożytnej Opowieści o Magach, gdzie mowa o „łagodnym i słodkim” głosie, wzywającym Mędrców do poznania tajemnicy ${ }^{91}$. Zbieżny z tekstem Jasłeczek jest fragment rodzimego tłumaczenia popularnej w Polsce Historii Trium Regum Jana z Hildesheimu:

Tedy [gwiazda] na tej górze jakoby słońce jasne wschodzić poczęła a oświeciła wszytkę wysokość niebieską [...]. A słyszan jest głos w onej gwieździe mówiąc: „Narodził sie jest dzisia król żydowski [...]”. A przeto ci to Trzej Królowie [...] z końmi, i z muły i z wielbłądy, i teże [z] skarby niewymownymi i też z barzo wielkim a niewymownym ludem i $\mathbf{z}$ wielkimi zastępy towarzystwa, jako najślachetniej a chędożej mogli ku szukaniu króla [...] są sie zgotowali. Jako głos

\footnotetext{
90 Alina Nowicka-Jeżowa łączy fragment o „głosie [...] niespodzianym” raczej z głosami aniołów wychwalającymi Boga (Łk 2,13-14). O „zarze różanej” mowa też w rotule Polihymnii (V. Rotuły, 9. Polihymnia). Krótką wzmiankę o „nowej [widniejącej na niebie] świecy" zawiera Szopa zbawienna (w. 124).

${ }^{1}$ Opowieść o Magach, w: Apokryfy Nowego Testamentu. Ewangelie apokryficzne, dz.cyt., s. 364. Na IV wiek datuje Opowieść o Magach Witold Witakowski (Witold Witakowski, Wstęp do Opowieści o Magach, w: Apokryfy Nowego Testamentu. Ewangelie apokryficzne, dz.cyt., s. 353).
} 
z tej to gwiazdy mówił a przykazał tako ślachetniej i poczciwiej są sie przyprawili [...] $]^{92}$ [podkr. P.G.].

Kasper Miaskowski, medytując nad tajemnicą Epifanii, jest ostrożny; przed zbyt łatwym odwoływaniem się do tradycji apokryficznej ustrzegły go może uchwały Tridentinum ${ }^{93}$. Usiłuje jednak wyjść poza lakoniczność narracji ewangelicznej, zastanawia się nad poprawną wersją zdarzeń - tym razem nie podaje alternatywnych wersji, lecz stawia pytanie („Co to za gwiazda [...] i głos?). Wyrażenie "goście wielcy” to z pewnością aluzja do królewskiego pochodzenia Mędrców (w Rotułach do Dzieciątka podążają „przednie osoby”, Rotuły, 2. Przemowa na rotuły, w. 137; o „królach” explicite mówi tytuł dziewiątego wiersza z cyklu Na Boże Narodzenie, utwór odwołuje się bowiem do nazwy święta) poświadczanego przez rozmaite apokryficzne teksty ${ }^{94}$. Autor Ewangelii gruzińskiej określa trzech tajemniczych przybyszów mianem: „wielcy królowie”95. O królewskim pochodzeniu Mędrców mowa też w Rozmyślaniu przemyskim, Historii Trzech Króli

\footnotetext{
92 Cały świat nie pomieściłby ksiag..., dz.cyt., s. 214-216.

93 Zob. Alina Nowicka-Jeżowa, Wstęp, w: Kasper Miaskowski, Zbiór rytmów, dz.cyt., s. 8 .

94 Hugo Kehrer wskazał, że to Tertullian jako pierwszy połączył Mędrców ze
} Wschodu z królami, o których mowa w Psalmie 71 (Ps 71,10), Hugo Kehrer, Die Heiligen Drei Könige in Literatur und Kunst, Leipzig 1908, s. 13. Istotne ustalenia na temat proweniencji motywu królów zawiera najnowsza książka Marka Starowieyskiego. Uczony pisze w niej, że „autorzy niektórych apokryfów i dość wcześni pisarze patrystyczni (np. Tertulian) zmienili ścisły termin Magoi, dość dokładnie lokalizujący przybywających do żłóbka, na szeroki termin 'królowie', który pozwalał im na puszczenie wodzy fantazji i wprowadzenie do fabuły apokryfów egzotyki, która stanowi jedną z cech charakterystycznych apokryfów. $\mathrm{Na}$ tę zmianę wpłynęło odniesienie do [...] epizodu Ps 71,10 n.” (Marek Starowieyski, Gwiazda Betlejemska w apokryfach, w: tegoż, Z historii wczesnego chrześcijaństwa. Biblia, męczennicy, poganie i inni, Kraków 2015).

95 Ewangelia gruzińska, w: Apokryfy Nowego Testamentu. Ewangelie apokryficzne, dz.cyt., s. 210-212, 214-215. Królewskie pochodzenie przypisuje się też Mędrcom w Ewangelii Arabskiej Jana („Magowie, którzy byli królami”, Ewangelia Arabska Jana, w: Apokryfy Nowego Testamentu. Ewangelie apokryficzne, dz.cyt., s. 237) i Opowieści o Magach („królowie, [...] zwani Magami”, Opowieść o Magach, w: Apokryfy Nowego Testamentu. Ewangelie apokryficzne, dz.cyt., s. 355). 
i Żywocie Pana Jezu Krysta ${ }^{96}$. Majestat postaci uwydatnia słowo „orszak”, nawiązujące zarazem do dużej liczby osób towarzyszących uczonym $^{97}$. W niektórych apokryfach monarchom towarzyszą ogromne karawany, liczące kilka tysięcy ludzi. Wystarczy wspomnieć choćby przytoczony wyżej fragment Historii Trzech Króli ${ }^{98}$.

Swoistą mieszankę tekstu kanonicznego i pozakanonicznego stanowią wzmianki poety o krajach tajemniczych wędrowców, inspirowane często fragmentem Psalmu $71^{99}$. Autor natchniony wymienia w nim mieszkańców Afryki, Tarsis, krajów arabskich i królestwa Saby ${ }^{100}$. Kasper Miaskowski lokuje ojczyznę Mędrców w Indiach, pisząc o rzece Ganges ${ }^{101}$ bądź wymieniając wprost nazwę kraju (10. Urania, w. 17-18). Indyjskie pochodzenie Mędrców ma prawdopodobnie swoje

96 Rozmyślanie o żywocie Pana Jezusa..., dz.cyt., s. 67; Baltazar Opeć, dz.cyt., k. List. XVv.

97 Podobną funkcję pełni - dość często stosowane przez poetę - słowo "poczty” (Szopa zbawienna, w. 123; Wiersze na Boże Narodzenie: 8. Na zaczynanie Nowego Roku, w. 45; 9. Na święto Trzech Królów, w. 1). Karawana nie może oczywiście obyć się bez zwierząt - w Szopie zbawiennej Mędrcy jadą na koniach (w. 125-126), w utworze Na zaczynanie Nowego Roku na „rączych wielbłądach” (w. 51).

${ }^{8}$ W Ewangelii gruzińskiej każdy z trzech królów zabrał ze sobą „cztery tysiące księży i cztery tysiące ludu” (Ewangelia gruzińska, w: Apokryfy Nowego Testamentu. Ewangelie apokryficzne, dz.cyt., s. 210-211), 12 tysięcy ludzi liczy też drużyna władców w Ewangelii Dzieciństwa Ormiańskiej (Ewangelia Dzieciństwa Ormiańska, w: Apokryfy Nowego Testamentu. Ewangelie apokryficzne, dz.cyt., s. 475. W Ewangelii Arabskiej Jana mowa o „trzech tysiącach ludzi”, którzy podróżowali razem z Mędrcami (Ewangelia Arabska Jana, w: Apokryfy Nowego Testamentu. Ewangelie apokryficzne, dz.cyt., s. 238). Motyw ten jest często wykorzystywany w sztuce występuje m.in. na przywołanym w przypisie 85. obrazie Domenica Ghirlandaio, a także na obrazie Adoracja Magów Sandra Botticellego (Sandro Botticelli, Adoracja Magów, Galeria Uffizi we Florencji, 1500).

99 Inspiracja psalmiczna widoczna jest m.in. w: Jasłeczkach, w. 73-74; pieśni Uranii (Rotuły, 10. Urania, w. 17-18) i utworze z cyklu Wierszy na Boże Narodzenie (8. Na zaczynanie Nowego Roku, w. 61-64).

${ }^{100}$ Przed nim będą padać Murzynowie [...]. Królowie Tarsis i wyspy przyniosą dary, królowie Arabscy i Saba przywiozą upominki (Ps 71,9-10) (Biblia w przekładzie księdza Jakuba Wujka, dz.cyt.).

101 Tak w: Jasłeczkach (w. 47), Szopie zbawiennej (w. 106) i Przemowie na rotuły (w. 135). 
źródło w literaturze apokryficznej - Indie były ojczyzną jednego z przybyszów według Ewangelii gruzińskiej i Ewangelii Dzieciństwa Ormiańskiej $^{102}$. Autor Historii Trzech Króli pisze o władcach,

[...] którzy w ziemiach onych, w Indyjej i w Persyjej, i w Kald<ej>ej krolowali $^{103}$.

Perskie korzenie Mędrców także zaintrygowały poetę. Smogorzewski twórca sugeruje je jednak bardzo subtelnie - przybyszom, adorującym Dzieciątko, usta Jezusa przypominają purpurę, „która zdobi perskie targi" (Szopa zbawienna, w. 154) ${ }^{104}$. W kwestii narodowości Mędrców poeta nie ma pewności (biblijna perykopa opowiadająca o pokłonie Mędrców zawiera tylko oględną wzmiankę lokującą kraje wędrowców na Wschodzie), podaje więc kilka różnych wersji. Sytuację tę najlepiej obrazuje fragment Przemowy na rotuly:

[...] tam, kędy wymiatają piaskmi na ostrowy bądź Indus, bądź Efrates, albo z opoczyst<éj> góry Tygrys, spychając pław swój przeźroczysty [...]

(V. Rotuly, 2. Przemowa na rotuly, w. 134-136)

Twórca nawiązuje nieraz do pochodzenia Mędrców w kontekście opisywanej uniwersalności zbawienia ${ }^{105}$.

${ }^{102}$ Ewangelia gruzińska, w: Apokryfy Nowego Testamentu. Ewangelie apokryficzne, dz.cyt., s. 210-211; Ewangelia Dzieciństwa Ormiańska, w: Apokryfy Nowego Testamentu. Ewangelie apokryficzne, dz.cyt., s. 475.

${ }^{103}$ Cały świat nie pomieściłby ksiąg..., dz.cyt., s. 215.

${ }^{104}$ Ojczyznę Mędrców w Persji lokują: Ewangelia gruzińska (Ewangelia gruzińska, w: Apokryfy Nowego Testamentu. Ewangelie apokryficzne, dz.cyt., s. 210), Ewangelia Dzieciństwa Ormiańska (Ewangelia Dzieciństwa Ormiańska, w: Apokryfy Nowego Testamentu. Ewangelie apokryficzne, dz.cyt., s. 475), Ewangelia Arabska Jana (Ewangelia Arabska Jana, w: Apokryfy Nowego Testamentu. Ewangelie apokryficzne, dz.cyt., s. 238) i utwory z Cyklu o Trzech Magach (Cykl o Trzech Magach, w: Apokryfy Nowego Testamentu. Ewangelie apokryficzne, dz.cyt., s. 350 n.).

105 Tak w rotule Uranii (V. Rotuły, 10. Urania, w. 17-18) i w wierszu Na zaczynanie Nowego Roku (VI. Wiersze na Boże Narodzenie, 8. Na zaczynanie Nowego Roku, w. 61-64). 
Imaginacja Kaspra Miaskowskiego nie oparła się sugestywnym bożonarodzeniowym motywom apokryficznym. Jednoznaczna i pewna odpowiedź na pytanie o przyczyny trwałości i żywotności niektórych bożonarodzeniowych komponentów pozakanonicznych w literaturze polskiej początków XVII wieku wydaje się niemożliwa, choć wyraźnie dostrzegalnym źródłem transmisji tych składników są przedstawienia ikonograficzne (nie można też zapominać o oddziaływaniu kolęd). Mimo ostrej krytyki fabulas aniles autorzy tego okresu obficie czerpią z bogatego zasobu apokryficznych miejsc wspólnych. Spora część motywów pozakanonicznych stanowiła jedynie utrwaloną w zbiorowej wyobraźni konkretyzację scen ewangelicznych (za przykład może tu posłużyć choćby miejsce narodzin Jezusa) i jako taka nie zagrażała katolickiej prawomyślności. Pozakanoniczne składniki rozszerzające tekst natchniony musiały natomiast mieścić się w granicach „wiarygodności narracji”"106. Najlepiej, jeśli były podparte autorytetem Ojców Kościoła. Dopiero wtedy służyły medytacji misterium.

\section{Summary \\ Apocryphal traditions in Christmas poems of Kasper Miaskowski}

The author, looking at the case of Christmas poems of Kasper Miaskowski, demonstrates the permanence and vitality of extra-canonical Christmas components in Polish literature of the early seventeenth century. She presents individual elements of narratio Nativitatis extant in the writings of the poet from Smogorzewo, searching for an answer to the question about the means of transmission of the described components.

\footnotetext{
${ }^{106}$ Alina Nowicka-Jeżowa, Wstęp, w: Kasper Miaskowski, Zbiór rytmów, dz.cyt., s. 8.
} 